\title{
ANALYSIS OF MARITIME CONTRACTS
}

\section{Seyed Amir Hossein Mahdavian ${ }^{1}$}

Maruthi T. $\mathrm{R}^{2}$

\begin{abstract}
The Increase of communication tools and development in transportation systems have led to the one of the transportation methods. These conventions do not apply to multimodal transportation contracts.
\end{abstract} expansion of international business relations. Consequently, new legal issues have emerged in international trade law. One of the effects of this expansion in the field of international freight transport is the increase in the use of multimodal transport in commodity exchanges among merchants all over the world which, of course, has made lawyers face more challenges. Today, transportation does not follow a single principle and the basis of transportation in various fields, especially in the field of maritime transportation, has changed. This area is one of the most important areas which are the starting point of changes in maritime transportation responsibility. Determining the law governing multimodal transport contracts is very important. Each of existing conventions on transportation is only applicable to

Keywords: Transportation contract, transport carrier, maritime transportation, convention,

\section{Introduction}

Since years ago, maritime transportation has been considered as one of the causes of the civilizations development. Through the history of Iran, mainly since Dariush, shipping and maritime transportion have always been one of the political, economic, social and security concerns of Iran (Taghizade, 2015). A contract is a credit inventory that is created by the concurrent will of two parties. The two parties' wills typically represent two different but consistent interests whom they are agreed with. Usually when concluding contracts, one party determines the conditions and the other has to accept

\footnotetext{
${ }^{1}$ Research Scholar, Department of Studies in Law, University of Mysore, Manasagangotri, Mysore, India.

2 Professor, Post Graduate Department of Studies in Law, University of Mysore, Manasagangotri, Mysore, India.
} 
them. In some cases, the regulations of some conventions on international single mode transportation are implemented on a multimodal international transport contract that has different rules in similar matters (Rokhchekav, 2017). United Nations Convention on Contracts for the International Carriage of Goods is included in rules which are complex but are in accordance with the new regulations in maritime transport industry. This research was conducted using descriptive-analytic. The descriptive method is based on the theory or the result of previous researches. Descriptive research addresses basic questions. Descriptive research is both practical and fundamental. In its practical application, this research is used for decision and policy making as well as planning. The data was collected using a library and scientific resources such as books, articles, journals, magazines, etc. Finally, the data was analyzed.

\section{1- The Concept of Maritime} Transportation

Maritime transportation can be defined by the following concepts:
1. Economic: Maritime transportation economically means the transportation of goods and passengers through the sea.

2. Legal: Maritime transport in the legal sense is considered as the contracts that are concluded for the accomplishment of such operations.

Today, maritime transportation has an important position in international trade. One of the most important aspects of maritime transportation is carrying the goods by containers. The strong point of marine transportation is not its speed. In other words, the most important benefit of it is the load carrying capacity and its continuity. Rail and road transportation are not as efficient as marine transportation since they cannot cover the geographic area of the loading and unloading the cargo. In heavy industry, maritime transportation is the most inexpensive and suitable type of transportation. Waterways are known as the most cost-effective means of transporting goods. Furthermore, the dominance of government over waterways is more due to more capacity of water transportation vehicles. Waterways are economic solution for 
maritime transportation (Saffarzad et al., 2010).

\subsection{International transportation}

International transportation of goods means moving and carrying goods from a point within a country to a point in another country, in accordance with the laws and regulations governing the contries. Article 513 of Iran Civil Code considers transportation contract as a lease stipulates that the main types of lease are as follows:

\section{Rental of crew and brokers of} any kind

Renting of transportation carriers who move people or property through land or water Article 516 of the Act says: "The obligations of carriers of transportation, whether through land or water is the same for those who protect and maintain the objects which are entrusted to them. If due to the responsible person's violation, the cargo is damaged or spoiled, the carrier is responsible. Since the cargo has been delivered, the carrier is responsible for any damage to it.
Considering the importance of today's transportation and trade, and that if the transportation contract is permissible, it may be subject to heavy losses due to non-fulfillment of commitments, it is necessary to consider the transportation contract singing as an essential part of the contract (Naghi Zadeh, 2012). The rules of Rotterdam, which is the full name of the United Nations Convention, is consist of international commodity transportation contract signing as general and partial.

\subsection{Excellence factor of maritime} transportation

A) Low cost of commodity transportation by sea: Commodity transportation by sea is cheaper than other methods. Through maritime transportation, several tones of commodity reache to the maritime boundary more suitable and cheaper than through thousands of kilometers long land. Furthermore, consumers, especially in the portal areas, can get the commodities with 
higher and more appropriate price.

B) Large volumes of commodity: Commodities with large volume and various dimensions are easily transportable by sea, so that only the ship can move this volume and size.

C) High weight of commodity: The ship is one of the few transportation vehicles that does not have a limit on heavy weights, and can relocate large amount of commodity at the same time. One of the advantages of this is that, the commodity transportation at this size and volume can supply the regional long-term needs.

D) Fast and safe commodity transportation: As there is no limitation for commodity transportation by the sea and since commodities are transported in shorter time, shipment by this method is safer and prevents from the problems that land and air transportations are faced.

\section{2- Maritime transportation carrier:}

Carrier is someone who has a job. The word "carrier" means undertake a work and do a job (Moein, M. 1985); and according to some jurists, it is included in a kind of continuation, repetition, duration, expertise and professionalism (Eskini, R. 2017). Shipment carrier includes the owner or tenant of the ship, who signs the contract with the shipper of the commodity (Paragraph A, Article One Hague Regulations). Iran Maritime Law adopted in 1965, defines the two terms of the cargo carrier and shipment carrier: ((The cargo carrier generally refers to the owner or renter of the ship, who has signed the contract with the shipper of the freight (paragraph 1, Article 52, of the Iran Marine Law adopted in 1965). From the phrase "Transportation tenure", it should be concluded that the persons who carries out transport operations for themselves aren't regarded as merchant since this is an ancillary activity which meets their needs. If the persons and institutions whose work is the transportation of other people's products to receive rent, carry out any other trade goods, they will be subject to the law trade (P 65). 


\section{Gênerger}

\section{3- Bill of lading}

Bill of lading is the document issued by the shipping company or its agent as a commodity receipt which determines the cost of shipment. In the bill of lading, the full specification of the freight is mentioned and signed by ship's captain and accordingly commits to deliver the freight by the ship to the destination. Each maritime lading bill or other similar documents, referring to the charter party agreement, determines the relationship between cargo carrier and the holder of the lading bill or the mentioned document as of the time of issue, shall be deemed to be a cargo contract (Barari Chenari, y. 2017 \& Jahanian, M.) The first definition of a maritime bill of lading is about maritime guidance, which defines bill of lading this way: The bill of lading is a document which is provided and issued by the ship owner mentioning the number and quality of the load, according to it, the loading is done and this document will be issued in three versions. UNCTAD published the Hamburg regulations in 1978. In paragraph 7, Article 1, Marine bill lading is defined as follows: The bill of lading is a document which according to maritime shipment contract signed.
The transporter receis commodity and commits to deliver it to the transferee of commodity whose name inserted in lading bill or the loaded vehicle. Given the definitions mentioned above, the lading bill can be defined as follows:

The bill of lading is the document, issued by the transporter or his agent after receiving the commodity and indicating the shipment of a certain commodity from one place to the other, by agreed shipment vehicle for specific shipment charge.

\section{4- Maritime transport contract and the liability in transportation contracts}

The maritime transport contract is concluded verbally in the initial and primary stages; but it is applied in one of the most appropriate types of transportation. These types are as follows: a) Charter Party, b) Bill of Lading, c) Special agreement. Transportation contracts have been encountered with various changes over the course of history. From verbal meeting past to present time that the buyer and the seller do not see each other, the bill of lading includes many complexities of this business. The 
history of the bill of lading begins with shipping, but it is not clear properly which date it has been customary to use the bill of lading. Regarding the damage to the commodity or the delay in the delivery of the goods, although the price of the goods is not paid to the owner of the goods as damage, and according to Article 387 of Business Law, the carrier has been liable for paying the compensation; however, compensation shall be calculated by reference to the price of the Goods. Even the legislator stipulates the aforesaid article below that the compensation cannot be exceed the compensation which may be provided in the respect of the loss of goods; therefore it is profited from above mentioned provisions is that in determining and calculating the compensation, the price of the goods shall be considered. The carrier is obliged to carry the goods in accordance with the terms and conditions. $\mathrm{He} / \mathrm{she}$ is liable for the total or partial loss of the goods and the damage occurred during the time of receipt of the goods from the sender and delivery to the recipient, as well as any delay in the delivery of the goods. However, He/she cannot be responsible if he/she can prove that the loss or damage or the delay in the
235

delivery of the goods due to default of complainant, the inherent corruption of the goods or conditions that it could not be avoided.

\section{5- The shipper's Responsibility in the Hague Convention}

The basis of responsibility in the Hague Provisions is the assumption of responsibility and there has no opposition to Islamic laws which governs Iran's rules and laws. All four foundations can be found in the texts of Islamic laws and the points of view and opinions of the jurists. Until the past century, the lawyers did not find any relation between the carriage contract for passenger and the loss and damage occurred during the journey. Therefore, due to lack of evidence of responsibility or fault, complainant was bound to prove the fault of carrier. This was not easy and facile and even impossible in some cases. To avoid this, lawyers provided a new interpretation of the carriage contract according to which the carrier obligation was propounded only a safety obligation that was mainly pledge to the outcome, as a contract infraction. To determine the basis of liability in the Hague Provisions is expanded and 
complicated, because examples of the assumption of the responsibility's fault are observed. This disorder and scattering shall be result from low accuracy of its compilers for enacting the explicit provisions of the Convention.

\section{6- The shipper's Responsibility in Hamburg Convention}

The primary goal of the compilers of this convention can be to provide regulations that contrary to the Brussels regulations will support more senders of goods in contrast with carriers. Concerning Hamburg Provisions, the carrier is liable for damage caused by the loss, damage to the goods and delay in delivery if the event occurred to cause loss or damage or delay during the period specified in Article 4, protected by the carrier. Unless the carrier proves himself/herself with his/her agents or commissioners have performed reasonably all necessary measures to avoid the consequences. Concerning above article, it can be found out what is not more than the intended fault, because the carrier is required to prove lack of relation of damage to himself/herself involved in presenting an evidence for reason of damage ,for

\section{6}

his/her exemption, of course is enough to prove the acts of care reasonable, not sever. The carrier is not bound to prove the cause of the damage, and only it is enough to prove that he/she has tried all his/her best not to do the fault.

According to Hamburg Rules, two of the seventeen exemptions can be seen in Hague Regulations (the fire and attempts to save lives or property at sea), it cannot be said that the basis of liability in this regulations is res ipsa loquitur. Considering the verdict of carrier in Hamburg rules, in such a situation, the basis of liability based on these rules can be concluded. Based on Hamburg rules, the carrier is liable for damages caused by vague reasons and will never be exempted therefore, it can be concluded that the basis of liability in Hamburg rule is assumed by liability. Unlike Hague, the Hamburg rules do not exclude the carriage of live animals from the inclusion of goods definition. These rules are about the carriage of live animals, although no specific provisions have been enacted.

\section{7- The liability of sea carrier in Rotterdam Convention}


The Rotterdam rules were established with the aim of governing the relationship between the carrier and the shipper in international trade that at least partly transported by sea. If this set of rules can be accepted among states, whether the ship-owner states or shipper states, it would not only replace the previous conventions, but also it can make states independent of using national or regional rules. Rotterdam rules can be a combination of methods of conventions (Hague and Hamburg) and it seems that it has created a new structure in liability's basis as well as action's burden of proof, by combining existing factors to get rid of current regularity defects. In accordance with the provisions of the Rotterdam Convention, the carrier is liable for the loss, damage and delay in delivery of the goods, while the shipper is liable for loss and damage of goods, but it has no reliability for delay in delivery of goods.

\section{8- Works of maritime carrier reliability}

The general rule of compensation is to restore former damaged status. Except in cases where the damage is in cash or partial, it is not possible to restore the former damaged status. In such cases, the meaning of this general rule is that the indemnity must restore the status of complainant to the condition that she or he had before the damage. If the corporeal property is available, the same must be returned, neither the obligor nor the obligee cannot make the each other to compensate through other way. If the corporeal property is defective, the person who is paying the compensation must make it sound and complete, and if there is not this possibility, then the price differential should be paid. The parties may, under the terms of the contract, due to a condition, determine a level of damage that must be paid in case of nonperformance of contract or detriment, this condition called "penalty clause". In case of detriment, compensation is limited to the same amount. According to paragraph 8 of Article 3 of the Brussels Convention, "mentioning any condition or agreement in carriage contract in order to make the carrier or the ship innocent from being liable for the damage to cargo, due to negligence in the performance of duties and explicit promises in this Article or its reduction will be null and void..." 


\section{9- Guarantee of implementation of passenger transportation breach of contract}

In Iran law, whenever an obligor fails to fulfill its obligations, the other party has no right to terminate the contract, but must first refer to the court to request the obligor requirement of performance. It can be said; firstly, there is a termination right for obligee in the event of a basic breach of contract by the obligor; secondly, this right can only be ruled out when besides detriment, Indigestion and embarrassment for obligor, he still can fulfill his obligations in spite of partial violations in a manner which has a noticeable utility for obligee; thirdly, whenever there is a nuisance in implementing of public evidence for the parties, the preference will be with obligee, since he had no negligence. Iran's Marine Law has anticipated the cases of this carriage contract termination in Articles 129 and 130 and cases of its legal dissolution in Article 131. According to Article 129 of the Iran's Marine Law: "the commander is required to directly peruse his path and travel to the destination, unless there is a specific contract or a deflection of route for saving individuals lives and properties

In case of violation, the passenger has the right to terminate the contract and seek to recovery his damages'. Apparently, legislators of maritime law, under the influence of the maritime transport rules inserted in the Article 5 of Brussels Convention 1924 (paragraph 4, Article 55 of Iran's Maritime Law), attempted to legislate mentioned article. (Houshang, 1973) The second article referred to the contract termination in Iran's Maritime Law, is the Article 130. According to this article, "If a ship does not move on a certain day due to the neglect or fault of the captain of the ship, the passenger has the right to terminate the contract and seek to recovery his damages'. Based on the contractual relationship between the passenger and a carrier and also the contractual nature of the damages occurred, which is the liability of failure to perform the commitment by the carrier, it appears that the liability for payment of damages occurred to the passenger is on the carrier not the captain of the ship. Iran's maritime law states in Article 131: "Whenever a ship cannot move due to the prohibition of trading to the destination port or the economic 
blockade of the destination port or force majeure, so the trip contract is rescinded and none of the parties has the right to claim the payment of occurred damages from the other party" (Andarz, et al. 2012).

\section{Conclusion}

The rights and commitments of each party of a transportation contract and the level of their liability are determined based on the substantive law governing on the contract; therefore, the determination of the governing law has a special significance and status. Basically, contract parties of the international multimodal transport can choose the governing law based on authority of will as far as imperative laws and morality allow it. Legal systems do not have a single approach regarding to the authority of will related to the contract parties in order to choose the governing law. Supplementary Protocol of Hague approved in 1968, despite its innovations, could not solve the problems of Hague laws and fully respond to the expectations. At the Treaty of Hamburg, new solutions were introduced according to the new techniques. These solutions have been properly considered among the stakeholders in the maritime transportation contract and its rules are enacted in accordance with the governing rules in other fields of transport. The Rotterdam Convention has considered the assumption of liability as the basis of carrier liability. While expressing the exemption of liability, it forces the carrier to determine and prove the cause of the incident in order to get rid of liability. In fact, return of Rotterdam regulations and accepted rules of Hague convention can be considered as the greatest effort to attract the companionship of maritime nations, so the present Convention shall not meet the fate of Hamburg regulations. In addition, Rotterdam Convention has also considered the liability of carrier in special cases and determined the level his liability. Obligations and liabilities of the carrier are limited to transport the commodities and do not conclude the transportation of passenger or luggage of passenger.

\section{Reference}

Eskini, R., (2016), Commercial law (general business transactions), 8th edition, SAMT publications. 
Houshang, O., (1973), Maritime law, Tehran, Volume 2, Tehran college of insurance, Third issue.

Andarz, D., Montazer, M., Masoodi, F., (2012), "Responsibility of maritime transportation carrier for the passenger in Iran's law", Journal of science-research of civil rights, Number 1.

Arian, M., Bagherian, A., (2015), Civil liability due to the aviation accidents against passengers, third parties and the environment, International conference on engineering science, Art and rights.

Barari Chenari, Y., Jahanian, M., (2016), "Issuance and contents of marine bill of lading in Iran's law and international documents", Law journal of justice, Number 80.

Taghizadeh, E., (2013), Rights of maritime transport, Majd Publications, Second edition.

Rabiei, F., (2007), Land, aviation and maritime transportation, Arian publications.

Rokhchekav, A., Governing law in the international multimodal transport of commodities, Master's thesis, Ferdowsi University of Mashhad, Faculty of economic and administrative sciences.

Sadeghi Neshat, A., (2014), "The right to terminate the contract, despite the requirement of performing in Iran's law", Journal of science-research, Number 4.

Safarzadeh, M., Azizabadi, A., Hamidi. H., Ali Shahba, M., (2009), Maritime transport, Asrar Danesh publications, Second edition.

Moein, M., (1983), Moin Encyclopedic Dictionary, Volume 1, edition 2, Amir Kabir publications, Tehran.

Naghizadeh Baghi, P., (2011) "The legal nature of the transportation contract and the liability of its carrier", Excellence of law, Number $13 \& 14$.

Hashemizadeh, A., (1999), The basis of the responsibility of commodity maritime transport carrier, Hamburg Rules and Islamic Law, Imam Sadiq University's research quarterly, Number 9.

Hoeks, M.A.I.H, (2008), “Multimodal Carriage with a Pinch of Sea Salt: Door 
to Door under the UNCITRAL Draft

Instrument”, ETL.

O'Sullivan, J. (2018). O'Sullivan and

Hilliard's the Law of Contract. Oxford

University Press.

Frederick, D. C. (1991), "Political participation and legal reform in the international maritime rulemaking process: from the Hague rules to the Hamburg rules", Journal of Maritime Law and Commerce, 22, 81.

United Nations convention on contracts for the international carriage of goods wholly or partly by sea 